\title{
Corneal epitheliopathy due to sensitive impairment: neurotrophic keratitis
}

\section{Epiteliopatía corneal por alteración sensitiva: queratitis neurotrófica}

\author{
Alejandro Babayán-Sosa* and Oscar Baca-Lozada \\ Fundación Hospital Nuestra Señora de la Luz, IAP, Mexico city, Mexico
}

\begin{abstract}
Neurotrophic keratitis is a degenerative disease characterized by corneal sensitivity reduction, spontaneous epithelium breakdown, and corneal healing impairment. Several causes of neurotrophic keratitis, including herpetic keratitis, diabetes, trauma and ophthalmic and neurosurgical procedures, share the common mechanism of trigeminal damage. Diagnosis requires accurate investigation of clinical ocular and systemic history, complete eye examination, and assessment of corneal sensitivity. Neurotrophic keratitis can be classified according to severity of corneal damage: superficial punctate keratitis (stage 1), persistent epithelial defect (stage 2), and perforation and melting (stage 3). Management is based on clinical severity, and aimed at promoting corneal healing and preventing progression of the disease to stromal melting and perforation. Currently, no specific medical treatment exists, and surgical approaches, such as amniotic membrane transplantation and conjunctival flap, are effective in preserving eye integrity, without improving corneal sensitivity or visual function.
\end{abstract}

Key words: Neurotrophic keratitis. Corneal sensitivity. Corneal innervation. Persistent epithelial defect. Trigeminal nerve.

\section{Resumen}

La queratitis neurotrófica es una enfermedad degenerativa corneal caracterizada por la reducción en la sensibilidad, una desepitelización y una reparación corneal ineficiente. Se han descrito muchas causas de queratitis neurotrófica, como la queratitis herpética, la diabetes, un trauma y las cirugías oftálmicas y neurológicas, que tienen en común el daño al nervio trigémino. El diagnóstico requiere un interrogatorio exhaustivo de los antecedentes oculares y sistémicos, un examen oftalmológico completo y la valoración de la sensibilidad corneal. La queratitis neurotrófica se clasifica de acuerdo al daño que se observa: queratitis punteada superficial (estadio I), defecto epitelial persistente (estadio II) y perforación y lisis (estadio III). El tratamiento se basa en la gravedad y está dirigido a promover la reepitelización y evitar la progresión de la enfermedad a lisis y perforación. Actualmente no existen tratamientos médicos específicos y los procedimientos quirúrgicos, como el injerto de membrana amniótica y el colgajo conjuntival, son efectivos para conservar la integridad del ojo, sin que se mejore la sensibilidad corneal o la visión.

Palabras clave: Queratitis neurotrófica. Sensibilidad corneal. Inervación corneal. Defecto epitelial persistente. Nervio trigémino.

Correspondence:

*Alejandro Babayán-Sosa

Col. Tabacalera, Del. Cuauhtemoc

C.P. 06030, Ciudad de México, México

E-mail: alejandro.babayan@gmail.com
Date of reception: 04-04-2017

Date of acceptance: 01-07-2017

DOI: 10.24875/RMOE.M18000017
Available online: 14-05-2018 Rev Mex Oftalmol (Eng). 2018;92(3):97-101 www.rmo.com.mx license (http://creativecommons.org/licenses/by-nc-nd/4.0/). 


\section{Introduction}

Neurotrophic keratitis or neurotrophic keratopathy is a rare degenerative disease that results from an alteration of corneal sensitivity, associated with epithelial defects, corneal ulcer, wound healing defects, corneal lysis and perforation ${ }^{1}$. Neurotrophic keratitis has been described as both primary (idiopathic) and secondary to various ocular and systemic diseases. Injury of the trigeminal corneal innervation is the usual pathogenic mechanism. Many ocular and neurological diseases can cause injury at different points of the corneal innervation: the trigeminal tract, ganglion or sensory fibers. The most frequent cause of corneal anesthesia in our country is viral infection (herpes simplex and herpes zoster keratitis), followed by chemical burns, physical injuries and corneal surgery. Intracranial lesions such as neuromas, meningiomas and aneurysms can also cause compression of the trigeminal nerve or ganglion and affect corneal sensitivity. Systemic diseases such as diabetes, multiple sclerosis and leprosy may decrease sensory function or directly damage the sensory fibers, leading to corneal anesthesia ${ }^{2-8}$. The clinical diagnosis is easily oriented based on medical history, but the management of this condition is one of the most difficult and challenging ones of all corneal diseases.

\section{Pathophysiology}

Exposure keratitis is a more appropriate term for the keratitis associated with seventh nerve palsy. The term neurotrophic keratitis should be reserved for corneal damage secondary to trigeminal lesions. The cornea contains one of the richest innervations of all body tissues. The corneal sensory nerves play a key role in maintaining the anatomical integrity and function of the cornea, particularly the epithelium. In the case of fifth nerve palsy, it is the loss of corneal sensitivity that produces a decrease in blinking causing epithelial defects, tear film evaporation and desiccation of the corneal epithelium due to exposure. The lack of blinking results in vasodilation of the eyelid margin and perilimbic vessels, as well as edema. Corneal and conjunctival epithelial damage in the area of the palpebral aperture becomes evident and later it may be accompanied by iritis, which manifests as flare and Tyndall in the anterior chamber. Epithelial cell membrane is damaged with subsequent cell death due to osmotic changes. Clinically, multiple and small epithelial defects occur in the exposed area, which subsequently increase in size.
Epithelial hyperplasia is observed as a compensation mechanism due to the irregularity of the surface in different areas of the cornea. There is a decreased rate of cellular mitosis and cellular migration. Initially the defects are repaired, but once there is a lesion in the Bowman's layer, it is not possible to fill those defects (irregular stromal surface that does not allow the rolling and adhesion of cells), which gives an appearance of increased epithelial thickness. The term ulceration can be considered from the moment in which all the epithelial layers are lost, including the basement membrane, leaving the Bowman layer exposed or the stroma exposed due to the loss of the latter. The presence of superficial neovessels is inevitable after a certain period of time and involves cellular loss, edema, inflammation and hypoxia, with epithelial and stromal ulcerations, sometimes infections and perforations. Stromal ulceration is secondary to degradation by proteolytic and collagenolytic enzymes. Damaged epithelial cells, conjunctival cells, fibroblasts and inflammatory cells ${ }^{9}$ can release these enzymes. Several studies have shown that the loss of corneal sensory innervation leads to a decrease in the metabolism and mitosis of epithelial cells and, consequently, to epithelial failure. Several studies have focused on the role of sensitive neuromediators in the physiopathology of the corneal epithelium. These studies have demonstrated the depletion of substance P (SP) and acetylcholine (Ach) in the rat cornea after a lesion of the sensory nerves in vitro, the SP, the calcitonin gene-related peptide (CGRP) and Ach ${ }^{10,11}$. Chikama, et al. achieved a complete recovery of neurotrophic keratitis in a patient treated with a combination of SP and insulin-like growth factor-1 (IGF-1) eye drops ${ }^{12}$. They inferred that the combination of SP and IGF-1 stimulates the migration of corneal epithelial cells and the expression of $\alpha 5$ and $\beta 1$ integrins, essential for the adhesion of epithelial cells to extracellular matrix proteins. Clinical and experimental evidence suggests bidirectional control of corneal epithelial proliferation: sensory neuromediators promote mitosis of epithelial cells while, on the other hand, sympathetic mediators, adrenaline and noradrenaline, reduce it.

\section{Epidemiology}

To our knowledge, there is no data in the literature about the epidemiology of neurotrophic keratitis. A prevalence of less than $5 / 10,00$ individuals is estimated. When we analyzed the prevalence of the main causes of neurotrophic keratitis, we found that $6 \%$ of herpes 
simplex keratitis develop this disorder, as well as $12.8 \%$ of herpes zoster keratitis and $2.8 \%$ of patients undergoing surgery for trigeminal neuralgia ${ }^{13-16}$.

\section{Causes}

The main ocular causes are herpetic keratitis (simplex and zoster), burns, trauma, dystrophies and some topical medications. Systemically, the causes of trigeminal damage are iatrogenic, neoplastic, multiple sclerosis, diabetes, leprosy, medications and congenital syndromes. The complete list is described in table 1.

\section{Diagnosis}

The essential step in the diagnosis of a neurotrophic keratitis is a thorough interrogation of the medical and surgical history in order to determine the cause of the corneal hypoesthesia. Systemic diseases such as diabetes mellitus or systemic therapies (neuroleptics, antipsychotics and antihistamines) can damage trigeminal corneal innervation. Surgery or corneal trauma, topical anesthetics abuse, chronic topical medications, chemical burns or contact lens overuse can locally damage corneal sensory nerves. Brain neoplasms and vascular accidents can compromise the fifth cranial nerve or its nucleus. A lesion of the seventh and fifth cranial nerves can occur in thyroid ophthalmopathy, an infiltrating periocular neoplasm, or after surgical resection of an acoustic neuroma. Aneurysms or cavernous sinus disease may cause alterations in ocular motility, while intraconal orbital lesions may be associated with optic nerve disorders and/or pupillary abnormalities. The presence of neurological signs requires co-management with the neurologist. A complete ophthalmologic examination should be performed. A corneal sensitivity test should be performed by touching the central and peripheral cornea with the tip of a cotton swab. As an alternative, the Cochet-Bonnet aesthesiometer may be used to locate and quantify the loss of corneal sensitivity, recording the patient's response to the touch of a nylon thread (between 0 and $6 \mathrm{~cm}$ ). These techniques do not allow the identification of the exact values of normal corneal sensitivity due to the measurement methods and the great variability of corneal sensitivity (depends on age, sex, area examined and time of the day). In general, the severity of neurotrophic keratitis is related to the level of corneal sensitivity lost. Schirmer test should be performed, since tear production can be affected by the reduction of corneal sensitivity. Fluorescein rose bengal or lissamine green staining shows
Table 1. Causes of neurotrophic keratitis

\begin{tabular}{|c|c|c|}
\hline Infectious & $\begin{array}{l}\text { Herpes Simplex } \\
\text { Herpes Zoster } \\
\text { Leprosy }\end{array}$ & $\frac{\infty}{0}$ \\
\hline Corneal disorders & $\begin{array}{l}\text { Burns } \\
\text { Contact lens overuse } \\
\text { Dystrophies } \\
\text { Surgeries }\end{array}$ & $\sum_{\frac{1}{d}}^{\frac{1}{d}}$ \\
\hline Topical medication & $\begin{array}{l}\text { Anesthetics (Tetracaine) } \\
\text { Beta blockers }\end{array}$ & (c) \\
\hline Trigeminal paresis (V) & $\begin{array}{l}\text { Surgery for trigeminal neur } \\
\text { Neoplasms } \\
\text { Aneurisms } \\
\text { Trauma } \\
\text { Congenital syndromes } \\
\text { Riley-Day } \\
\text { Möbius }\end{array}$ & 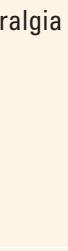 \\
\hline Systemic diseases & $\begin{array}{l}\text { Diabetes mellitus } \\
\text { Vitamin A deficiency } \\
\text { Multiple sclerosis }\end{array}$ & $\begin{array}{l}\frac{c}{0} \\
\frac{\tilde{n}}{\varepsilon} \\
\frac{\tilde{c}}{\varepsilon}\end{array}$ \\
\hline
\end{tabular}

corneal and conjunctival epithelial changes. The examination of the position and motility of the palpebral margin is important, since exposure keratitis and blepharitis may be associated with neurotrophic keratitis. The pupils and cranial nerves should be examined looking for signs suggestive of intracranial disease $\mathrm{e}^{17-19}$.

\section{Differential diagnosis}

Superficial punctate keratopathy and tear film abnormalities, which characterize stage I disease, are frequent in other ocular diseases such as dry eye, exposure keratitis, topical drug toxicity, and contact lens overuse. The presence of ocular symptoms such as burning, foreign body sensation, photophobia and dry eye direct the diagnosis towards other ocular surface diseases; corneal anesthesia is characteristic of neurotrophic keratitis. Superficial corneal vascularization and an epithelial defect can also be seen in limbal stem cell deficiency. In this case, impression cytology can allow the identification of the epithelial phenotype by cytokeratin immunohistochemistry (the corneal epithelium is cytokeratin-3 positive and cytokeratin-19 negative, while the conjunctival epithelium is cytokeratin-19 positive and cytokeratin-3 negative) ${ }^{20}$. However, diseases that cause limbal deficiency may damage sensory corneal nerves and cause neurotrophic keratitis. Infectious, toxic or immune ulcers always have significant ocular inflammation, stromal infiltrates and symptoms. Microbiological tests for bacteria, fungi and virus are always required; post-herpetic corneal ulcers may be associated with an active viral infection. Any local treatment should be 
suspended to exclude toxic corneal ulcers and a systemic evaluation to detect immune alterations should be considered.

\section{Classification}

Punctate keratopathy, hyperplasia and epithelial irregularity, superficial neovascularization and stromal scarring characterize stage I. Stage II is characterized by the presence of a persistent epithelial defect, most frequently located in the upper half of the cornea. Usually, around the epithelial defect there is an area of poorly adhered, opaque and edematous epithelium that can detach spontaneously and lead to an increase in the size of the defect. Epithelial wound healing is inadequate and the borders of the defect curl. Folds in Descemet's membrane and stromal edema with an inflammatory reaction in the anterior chamber may also be observed; rarely, sterile hypopyon may appear. Stage III is characterized by stromal involvement, with a corneal ulcer that can progress to perforation and/or stromal lysis. The summary of the stages is displayed in table 2.

The objectives of the treatment of neurotrophic keratitis are to prevent the progression of corneal damage and improve corneal transparency. Therapy must be initiated early and based on the clinical stage of the disease. In stage I therapy aims to improve epithelial quality and transparency, and avoid epithelial defects. It is mandatory to discontinue all topical medications, if possible, and consider the possible adverse effects of systemic therapies such as neuroleptics, antipsychotics and antihistamines. Preservative-free eye drops can help improve the corneal surface. Corneal or scleral therapeutic contact lenses may be used, but they may increase the risk of secondary infections and cause sterile hypopyon, so their use should be limited ${ }^{21}$. Other corneal surface diseases such as exposure keratitis, dry eye and limbal deficiency, if associated with neurotrophic keratitis, worsen the prognosis of the disease and require specific treatment. In these cases, it is important to correct the palpebral dysfunction and consider a limbal stem cell transplantation. In stage II, the objectives of treatment are to avoid the formation of a corneal ulcer, promote healing of the epithelial defect and prevent de-epithelialization recurrence. Interruption of all topical medications is always required, and corneal surface can be improved by the use of preservative-free artificial tears. Patients should be carefully monitored because the progression of the disease is often asymptomatic. In case of corneal ulcers that
Table 2. Mackie classification

\begin{tabular}{l|l|} 
Stage 1 & $\begin{array}{l}\text { Superficial punctate keratitis } \\
\text { Shortened TBUT } \\
\text { Inferior conjunctival staining } \\
\text { Scarring }\end{array}$ \\
\hline Stage 2 & $\begin{array}{l}\text { Epithelial defect } \\
\text { Corneal edema } \\
\text { Loose epithelium }\end{array}$ \\
\hline Stage 3 & $\begin{array}{l}\text { Persistent ulcer } \\
\text { Stromal lysis } \\
\text { Perforation }\end{array}$ \\
\hline
\end{tabular}

do not respond to artificial tears or therapeutic contact lenses, tarsorrhaphy is the most used and simple procedure. If healing is achieved, tarsorrhaphy removal can be performed after a few weeks, but a premature removal may result in recurrence of the corneal epithelial defect ${ }^{22}$. As an alternative, it is possible to cover the epithelial defect with an amniotic membrane graft or to use a palpebral weight or an injection of botulinum toxin A in the levator palpebrae superioris muscle ${ }^{23}$. In stage III, therapy is aimed at promoting corneal healing and preventing corneal lysis and perforation. As in stages I and II, it is important to avoid the toxic effects of topical treatments, hence only the use of preservative-free artificial tears is suggested. Tarsorrhaphy and conjunctival flap are effective procedures to promote corneal healing, but they cause a decrease in vision and are not very aesthetic ${ }^{24}$. Small perforations, smaller than $2 \mathrm{~mm}$, can be treated with the application of tissue adhesives ${ }^{25}$. Major defects require lamellar or penetrating keratoplasty ${ }^{26}$. Success rates of these corneal transplants are low due to the poor healing of the wound and the persistent risk of epithelial defects due to corneal anesthesia. Reed, et al. found that $75 \%$ of 12 patients with corneal leukoma secondary to herpes zoster keratitis and corneal hypoesthesia maintained a clear corneal graft ${ }^{27}$.

\section{Prognosis}

Neurotrophic keratitis represents one of the most difficult and challenging eye diseases that still lacks a standardized treatment. The prognosis depends on several factors such as the cause of the injury that affected corneal sensitivity, the degree of anesthesia or corneal hypoesthesia and the association with other ocular surface diseases such as dry eye, exposure keratitis and limbal deficiency. In general, the severity of corneal sensitivity loss is proportional to the likelihood of disease progression. It is important to remind 
the patient that frequent examinations are necessary, since the disease usually lacks signs and symptoms, and that protection with preservative-free artificial tears can prevent epithelial defects. Currently, the treatment of neurotrophic keratitis is still conservative, and any surgical procedure aimed at restoring corneal transparency should be avoided due to the high risk of epithelial defects, ulcers, corneal lysis and perforation after surgery.

\section{Conclusion}

Neurotrophic keratitis is a degenerative corneal disease characterized by a decrease in corneal sensitivity resulting from damage to trigeminal innervation. The aim of the treatment is to prevent damage increase and to promote an adequate epithelial migration. The study of neurotransmitters and their application provides a future therapeutic option ${ }^{28}$.

\section{Ethical disclosures}

Protection of human and animal subjects. The authors declare that no experiments were performed on humans or animals for this study.

Confidentiality of data. The authors declare that no patient data appear in this article.

Right to privacy and informed consent. The authors declare that no patient data appear in this article.

\section{Funding}

No funding has been received.

\section{Conflict of interest}

The authors declare no conflicts of interest.

\section{References}

1. Mackie IA. Neuroparalytic keratitis. En: Fraunfelder F, Roy FH, eds. Current ocular therapy. 4.a ed. Filadelfia; 1995. p. 506-8.
2. Cobo LM. Corneal complications of herpes zoster ophthalmicus. Prevention and treatment. Cornea. 1988;7(1):50-6.

3. Rosenwasser GO, Holland S, Pflugfelder SC, Lugo M, Heidemann DG, Culbertson WW, et al. Topical anesthetics abuse. Ophthalmology. 1990; 97(8):967-72.

4. Varga JH, Subinfeld RS, Wolf TC, Stutzman RD, Peele KA, Clifford WS, et al. Topical anesthetic abuse ring keratitis: Report of four cases. Cornea. 1997:16(4):424-9.

5. Weissman SS, Asbell PA. Effects of topical timolol $(0.5 \%)$ and betaxolol (0.5\%) on corneal sensitivity. Br J Ophthalmol. 1990;74(7):409-12.

6. Szerenyi K, Sorken K, Garbus JJ, Lee M, McDonnell PJ. Decrease in normal human corneal sensitivity with topical diclofenac sodium. Am J Ophthalmol. 1994;118(3):312-5

7. Hyndiuk RA, Kazarian EL, Schultz RO, Seideman S. Neurotrophic corneal ulcers in diabetes mellitus. Arch Ophthalmol. 1977:95(12):2193-6.

8. Karacorlu MA, Cakiner T, Saylan T. Corneal sensitivity and correlations between decreased sensitivity and anterior segment pathology in ocular leprosy. Br J Ophthalmol. 1991;75(2):117-9.

9. Foster CS. Corneal Manifestations of Neurologic Diseases. En: Smolin G, Thoft RA. The Cornea. 3.a ed. Boston: Little, Brown and Company; 1994.

10. Cavanagh HD, Colley AM. The molecular basis of neurotrophic keratitis. Acta Ophthalmol Suppl. 1989;192:115-34.

11. Kingsley RE, Marffurt CF. Topical substance $P$ and corneat epithelia wound closure in the rabbit. Invest Ophthalmol Vis Sci. 1997;38(2):388-95.

12. Chikama T, Fukuda K, Morishige N, Nishida T. Treatment of neurotrophic keratopathy with substance-P-derived peptide (FGLM) and insulin growth factor 1. Lancet. 1998;351(9118):1783-4.

13. Labetoulle M, Auquier P, Conrad H, Crochard A, Daniloski M, Bouée S, et al. Incidence of herpes simplex virus keratitis in France. Ophthalmology. 2005;112(5):888-95.

14. Hamrah P, Cruzat A, Dastjerdi MH, Zheng L, Shahatit BM, Bayhan HA, et al. Corneal sensation and subbasal nerve alterations in patients with herpes simplex keratitis: an in vivo confocal microscopy study. Ophthalmology. 2010;117(10):1930-6.

15. Dworkin RH, Johnson RW, Breuer J, Gnann JW, Levin MJ, Backonja M, et al. Recommendations for the management of herpes zoster. Clin Infect Dis. 2007;44 Suppl 1:S1-26.

16. Bhatti MT, Patel R. Neuro-ophthalmic considerations in trigeminal neuralgia and its surgical treatment. Curr Opin Ophthalmol. 2005;16(6):334-40.

17. Belmonte C, Acosta MC, Schmelz M, Gallar J. Measurement of corneal sensitivity to mechanical and chemical stimulation with a $\mathrm{CO} 2$ esthesiometer. Invest Ophthalmol Vis Sci. 1999;40(2):513-9.

18. Heigle TJ, Pukfelder SC. Aqueous tear production in patients with neurotrophic keratitis. Cornea. 1996;15(2):135-8.

19. Sacchetti M, Lambiase A. Diagnosis and management of neurotrophic keratitis. Clini Ophthalmol. 2014:8:571-9.

20. Sacchetti M, Lambiase A, Cortes M, Sgrulletta R, Bonini S, Merlo D, et al. Clinical and cytological findings in limbal stem cell deficiency. Graefes Arch Clin Exp Ophthalmol. 2005;243(9):870-6.

21. Grey F, Carley F, Biswas S, Tromans C. Scleral contact lens management of bilateral exposure and neurotrophic keratopathy. Cont Lens Anterior Eye. 2012;35(6):288-91.

22. Lambiase A, Rama P, Aloe L, Bonini S. Management of neurotrophic keratopathy. Curr Opin Ophthalmol. 1999;10(4):270-6.

23. Kirkness CM, Adams GGW, Dilly PN, Lee JP. Botulinum toxin $\bar{A}$-induced protective ptosis in corneal disease. Ophthalmology. 1988:95(4):473-80.

24. Khodadoust A, Quinter AP. Microsurgical approach to the conjunctival flap. Arch Ophthalmol. 2003;121(8):1189-93.

25. Khokhar S, Natung T, Sony P, Sharma N, Agarwal N, Vajpayee RB. Amniotic membrane transplantation in refractory neurotrophic corneal ulcers: a randomized, controlled clinical trial. Cornea. 2005;24(6):654-60.

26. Jhanji V, Young AL, Mehta JS, Sharma N, Agarwal T, Vajpayee RB. Management of corneal perforation. Surv Ophthalmol. 2011:56(6):522-38.

27. Reed JW, Joyner SJ, Knauer WJ $3^{\text {rd }}$. Penetrating keratoplasty for herpes zoster keratopathy. Am J Ophthalmol. 1989;107(3):257-61.

28. Lambiase A, Sacchetti M, Bonini S. Nerve growth factor therapy for corneal disease. Curr Opin Ophthalmol. 2012;23(4):296-302. 